\title{
Performance of Frontline Demonstrations on Productivity and Profitability of Black Gram (Vigna mungo) Through Improved Technologies under Rainfed Conditions
}

\author{
K.V. Sahare ${ }^{1}$, B.K. Tiwari ${ }^{2}$, K.P. Tiwari ${ }^{1}$, R.R. Singh ${ }^{1}$, K.S. Baghel ${ }^{2}$ and Smita Singh ${ }^{2}$ \\ ${ }^{1}$ JNKVV, Krishi Vigyan Kendra, Umaria, Madhya Pradesh-484661, India \\ ${ }^{2}$ JNKVV, Krishi Vigyan Kendra, Rewa, Madhya Pradesh-486001, India \\ *Corresponding author
}

\begin{abstract}
A B S T R A C T
Keywords

Front line

demonstration,

Black gram, Yield,

$\mathrm{BC}$ ratio

Article Info

Accepted:

10 September 2018

Available Online:

10 October 2018

The present study was carried out the evaluating the performance of improved varieties with scientific package and practices on production, productivities and profitability of black gram. Front line demonstrations were conducted during 2009-10 to 2013-14 (five consecutive years) with evaluation of the performance of different varieties of black gram (PU-35, IPU 94-1 and T-9) in five different villages namely Lorha, Choti pali, Chandia, Dogargawa and Tali of the district. The results showed that the average mean yield of black gram under front line demonstrations was $8.07 \mathrm{q} / \mathrm{ha}$ as compared to $5.06 \mathrm{q} / \mathrm{ha}$ recorded in farmer's practices, average yield increase of $60 \%$ and additional return of Rs 7774/ha. It was observed that the benefit cost ratio (B: C ratio) of recommended practice was 2.28 as compared to 1.72 in farmer's practice as per the mean of five consecutive years i.e. $2009-10$ to 2013-14. The average extension gap $3.01 \mathrm{q} / \mathrm{ha}$ and average technology gap $3.93 \mathrm{q} /$ ha was recorded. Therefore, the results clearly indicates that the use of improved varieties and package and practices with scientific intervention under front line demonstration programme contribute to increase the productivity and profitability of pulses in the district.
\end{abstract}

\section{Introduction}

Grain legumes are being cultivated in India since time immemorial. They have high protein content (20-26\%) and can be considered as a natural supplement to cereals. After fish (dry) which provides $335 \mathrm{~g}$ protein per $\mathrm{kg}$, grain legume provides 220-250 g protein per $\mathrm{kg}$. Hence legumes are considered as a "poor man's meet". The green revolution has not increased the productivity of pulses; instead its emphasis on cereals has often led to decreased legume production. Therefore in the present context of our economic development exploitation of legumes in the diet in combination with cereals to make it nutritionally balanced appears to be the only feasible approach to eliminate "Protein calorie" malnutrition in the near future.

Black gram is an important pulse crop grown during the month of June in almost area of Madhya Pradesh. Mostly it has grown in rainfed conditions, after its harvest farmers 
mostly growing wheat under irrigated conditions while fallow in rainfed conditions. The productivity is very poor $(300-400 \mathrm{~kg} / \mathrm{ha})$. The poor yield of black gram is mainly attributed to the use of poor quality seeds, poor germination of seeds, water stress at flowering stage, no ferilizer application, no YMV management and no weed management. Umaria district has the low productivity (220 $\mathrm{kg} / \mathrm{ha}$ during 2009). The irrigated area of Umaria is only $25 \%$ and more than $50 \%$ soils are sandy-light soils, poor water holding capacity, sloppy land etc. are augmenting the increasing the area of short duration, less water requiring crop like black gram in the district. The black gram crop has more importance in adverse soil and topographic area in rainfed conditions. The reason of low productivity may be attributed to non-adoption of improved production technology which includes the agronomic practices and socioeconomic conditions of the tribal peoples. The productivity of black gram in the district can be increase by fallowing the appropriate agronomic practices along with high yielding black gram varieties. Farmers are growing local seeds; no seed treatment, broadcasting method of sowing, no weed management practices adopted, severe incidence of YMV, no nutrient management etc are the basic reasons of low productivity of black gram in the district. An effort made by the KVK scientists by introducing the new agro techniques of black gram production through front line demonstration on farmers field during five consecutive years of kharif seasons from 2009-10 to 2013-14.

\section{Materials and Methods}

Field demonstrations were conducted in Umaria district of Madhya Pradesh under close supervision of Krishi Vigyan Kendra. Total 65 front line demonstrations under real farming situations were conducted during kharif seasons of 2009-10 to 2013-14 (five consecutive years) at five different villages namely; Lorha, Chhotipali, Chandia, Dogargawa and Taali, respectively under Krishi Vigyan Kendra operational area. The area under each demonstration was 0.4 ha. The soil was sandy -loam in texture with low water holding capacity, low to medium in organic carbon (0.030-0.052\%), low in available nitrogen (110.2-206.7 kg/ha), medium in available phosphorus (11.9-17.4 $\mathrm{kg} / \mathrm{ha}$ ), low to medium in available potassium (211.4-292.3 kg/ha) and soil $\mathrm{pH}$ was slightly acidic to neutral in reaction (6.5-7.1). The treatment comprised of recommended practice $v s$ farmers practice. The treatment comprised of recommended practice (Improved varieties ie PU-35, IPU 94-1 \& T-9), seed treatment with thiamethoxam 30\% FS @ $10 \mathrm{ml} / \mathrm{kg}$ seeds, integrated nutrient management-@ 20:50:20:20 kg NPKS/ha + Rhizobium + PSB (a) $5 \mathrm{~g} / \mathrm{kg}$ seed, seed treatment with Trichodermaviridae@5 g/kg seed etc.vs. farmers practice. Crop was sown between 7 July to 13 July with a seed rate was $15 \mathrm{~kg} / \mathrm{ha}$.

An entire dose of $\mathrm{N}, \mathrm{P}_{2} \mathrm{O}_{5}, \mathrm{~K}_{2} \mathrm{O}$ and $\mathrm{S}$ were given as basal through Urea, Single Super Phosphate (SSP), muriate of potash and elemental sulphur, respectively. The seeds were treated with Trichoderma viridae @5 $\mathrm{g} / \mathrm{kg}$ seeds then inoculated by Rhizobium and phospho-solubilizing bacteria biofertilizers each $5 \mathrm{~g} / \mathrm{kg}$ of seeds. Application of Imazethapyr @100 g a.i./ha at 20-25 DAS for effective weed management; used flat fan nozzle. The demonstrations were conducted under rainfed conditions. The crop was harvested between $28^{\text {th }}$ September and $10^{\text {th }}$ October during all years of demonstration (2009-10 to 2013-14). Farmer's practice constituted growing unidentified local varieties seeds with higher seed rate (25-30 $\mathrm{kg} / \mathrm{ha}$ ), broadcasting method of sowing, no seed treatment, no biofertilizer inoculation, not apply the fertilizers, no weed management practices adopted etc. 
Harvesting and threshing operations done manually; $5 \mathrm{~m} \times 3 \mathrm{~m}$ plot harvested in 3 locations in each demonstration and average grain weight taken at $10 \%$ moisture. Similar procedure adopted on FP plots under each demonstration then grain weight converted into quintal per hectare $(\mathrm{q} / \mathrm{ha})$. Before conduct the demonstration training to farmers of respective villages was imparted with respect to envisaged technological interventions.

All other steps like site selection, farmers selection, layout of demonstration, farmers participation etc. were followed as suggested by Choudhary (1999). Visits of farmers and extension functionaries were organized at demonstration plots to disseminate the technology at large scale. Yield data was collected from farmers practice and demonstration plots; cost of cultivation, net income and benefit cost ratio were analyzed. To estimate the technology gap, extension gap and technology index, following formulae given by Yadav et al., (2004) have been used.

Technology gap $=$ Potential yielddemonstration yield

Extension gap $=$ demonstration yield-farmer's practice yield

(Potential yield-demonstration yield) Technology Index = --------------------- x 100 Potential yield

\section{Results and Discussion}

\section{Grain yield}

The yield performance and economic indicators are presented in Table 1. The data revealed that under demonstration plot, the performance of black gram yield was found to be higher than that under FP during five consecutive years of demonstrations (2009-10 to 2013-14). The yield of black gram under demonstration recorded was 7.38, 7.11, 8.50, 8.96 and $8.40 \mathrm{q} /$ ha during 2009-10, 2010-11, 2011-12, 2012-13 and 2013-14, respectively. The yield enhancement due to technological intervention was to the tune of $46 \%$ to $78 \%$ over FP. The cumulative effect of the technological intervention over five years, revealed on average yield of $8.07 \mathrm{q} / \mathrm{ha}, 60 \%$ higher over FP. The year to year fluctuations in yield and cost of cultivation can be explained on the basis of variations in prevailing social, economical and prevailing microclimatic condition of that particular village especially adverse climatic conditions. The yield attributing character of front line demonstration i.e. number of pods per plant was higher (56/plant) over farmer's practice (32/plant) on five years average. The avove findings were accordance with Dubey et al., (2010). Gurumukhi and Mishra (2003) have also reported that depending on identification and use of farming situation, specific intervention may have greater implications in enhancing systems productivity. Yield enhancement in different crops in front line demonstration has amply been documented by Sharma (2003), Tiwari et al., (2003) and Tomar et al., (2003).

\section{Economics}

Economic indicators i.e. gross expenditure, gross returns, net returns and $\mathrm{B}$ : $\mathrm{C}$ ratio of front line demonstration is presented in Table 2 . The data clearly revealed that the net return from the recommended practice were substantially higher than FP plot during 200910 to 2013-14 (five consecutive years of demonstration). Average net returns from recommended practice were observed to be Rs. $14505 /$ ha in comparison to FP plot i.e. Rs 6732/ha. On an average Rs. 7774/ha as additional income is attributed to the technological intervention provided in demonstration plots i.e. recommended practices. 
Table.1 Productivity, yield parameters, technology gap, extension gap and technology index of black gram as affected by recommended practices as well as farmer's practice under rainfed conditions

\begin{tabular}{|c|c|c|c|c|c|c|c|c|c|c|c|c|}
\hline \multirow[t]{2}{*}{ Year } & \multirow{2}{*}{$\begin{array}{c}\text { Are } \\
\mathbf{a} \\
\text { (ha) }\end{array}$} & \multirow[t]{2}{*}{$\begin{array}{l}\text { No. of } \\
\text { farmers }\end{array}$} & \multirow[t]{2}{*}{ Variety } & \multicolumn{2}{|c|}{$\begin{array}{c}\text { No. of } \\
\text { pods/plant }\end{array}$} & \multicolumn{3}{|c|}{ Grain yield (q/ha) } & \multirow{2}{*}{$\begin{array}{c}\% \\
\text { increase } \\
\text { over FP }\end{array}$} & \multirow[t]{2}{*}{$\begin{array}{l}\text { Technology } \\
\text { gap (q/ha) }\end{array}$} & \multirow[t]{2}{*}{$\begin{array}{l}\text { Extension gap } \\
\qquad(\mathbf{q} / \mathbf{h a})\end{array}$} & \multirow[t]{2}{*}{$\begin{array}{l}\text { Technology } \\
\text { index }(\%)\end{array}$} \\
\hline & & & & $\mathbf{R P}$ & FP & Potential & RP & FP & & & & \\
\hline $2009-10$ & 5.0 & 13 & PU-35 & 48 & 31 & 12 & 7.38 & 4.83 & 53 & 4.62 & 2.55 & 38.50 \\
\hline $2010-11$ & 5.0 & 13 & IPU-94-1 & 41 & 25 & 12 & 7.11 & 4.51 & 58 & 4.89 & 2.60 & 4075 \\
\hline 2011-12 & 5.0 & 13 & PU-35 & 61 & 39 & 12 & 8.50 & 5.81 & 46 & 3.50 & 2.69 & 29.16 \\
\hline 2012-13 & 5.0 & 13 & PU-35 & 73 & 31 & 12 & 8.96 & 5.03 & 78 & 3.04 & 3.93 & 25.33 \\
\hline 2013-14 & 5.0 & 13 & T-9 & 57 & 36 & 12 & 8.40 & 5.12 & 64 & 3.60 & 3.28 & 30.00 \\
\hline $\begin{array}{l}\text { Total/ } \\
\text { Mean }\end{array}$ & 25 & 65 & -- & 56 & 32 & 12 & 8.07 & 5.06 & 60 & 3.93 & 3.01 & 32.74 \\
\hline
\end{tabular}

Table.2 Economics of front line demonstration of black gram as affected by recommended practices as well as farmer's practices under rainfed conditions

\begin{tabular}{|c|c|c|c|c|c|c|c|c|c|c|c|c|c|}
\hline \multirow[t]{2}{*}{ Year } & \multirow[t]{2}{*}{$\begin{array}{c}\text { No. of } \\
\text { demonstration }\end{array}$} & \multicolumn{2}{|c|}{ Yield (q/ha) } & \multirow[t]{2}{*}{$\begin{array}{l}\% \text { increase } \\
\text { over FP }\end{array}$} & \multicolumn{2}{|c|}{$\begin{array}{c}\text { Gross } \\
\text { expenditure } \\
\text { (Rs/ha) }\end{array}$} & \multicolumn{2}{|c|}{$\begin{array}{l}\text { Gross returns } \\
\text { (Rs/ha) }\end{array}$} & \multicolumn{2}{|c|}{$\begin{array}{l}\text { Net returns } \\
\text { (Rs/ha) }\end{array}$} & \multirow[t]{2}{*}{$\begin{array}{c}\text { Additional } \\
\text { net return } \\
\text { (Rs/ha) }\end{array}$} & \multicolumn{2}{|c|}{ B:C ratio } \\
\hline & & $\mathbf{R P}$ & FP & & $\mathbf{R P}$ & FP & $\mathbf{R P}$ & FP & $\mathbf{R P}$ & FP & & $\mathbf{R P}$ & FP \\
\hline 2009-10 & 13 & 7.38 & 4.83 & 53 & 10445 & 8657 & 23616 & 15456 & 13171 & 6799 & 6372 & 2.26 & 1.78 \\
\hline $2010-11$ & 13 & 7.11 & 4.51 & 58 & 10445 & 8657 & 22752 & 14432 & 12307 & 5775 & 6532 & 2.17 & 1.66 \\
\hline 2011-12 & 13 & 8.50 & 5.81 & 46 & 10445 & 8657 & 27200 & 18592 & 16755 & 9935 & 6820 & 2.60 & 2.14 \\
\hline 2012-13 & 13 & 8.96 & 5.03 & 78 & 12841 & 10665 & 28672 & 16096 & 15831 & 5431 & 10400 & 2.23 & 1.50 \\
\hline 2013-14 & 13 & 8.40 & 5.12 & 64 & 12417 & 10665 & 26880 & 16384 & 14463 & 5719 & 8744 & 2.16 & 1.53 \\
\hline $\begin{array}{l}\text { Total/ } \\
\text { Mean }\end{array}$ & 65 & 8.07 & 5.06 & 60 & 11319 & 9460 & 25824 & 16192 & 14505 & 6732 & 7774 & 2.28 & 1.72 \\
\hline
\end{tabular}


Economic analysis of the yield performance revealed that benefit cost ratio of demonstration plots were observed significantly higher than FP plots. The benefit cost ratio of demonstration and FP plots were $226,2.17,2.60,2.23,2.16$ and $1.78,1.66$, $2.14,1.50,1.53$ during $2009-10$ to $2013-14$, respectively. Hence favorable benefit cost ratios proved the economic viability of the intervention made under demonstration and convinced the farmers on the utility of intervention. The data clearly revealed that the maximum increase in yield and benefit cost ratio observed was 8.96 and 2.60 , respectively during $2012-13$. The variation in benefit cost ratio during all the years may mainly on account of yield performance and input output cost in that particular years.

\section{Extension and technology gap}

The extension gap ranging between 2.55-3.93 $\mathrm{q} / \mathrm{ha}$ during the period of study emphasized the need to educate the farmers through various means for the adoption of improved agricultural production to reverse the trend of wide extension gap (Table 1). The trend of technology gap ranging between 2.55-3.93 $\mathrm{q} / \mathrm{ha}$ reflected the farmer's cooperation in carrying out such demonstration with encouraging results during 2009-10 to 201314. The technology gap observed may be attributed to the dissimilarity in weather conditions. The technology index showed the feasibility of the evolved technology at the farmer's field.

The lower the value of technology index, the more is the feasibility of the technology. As such, the reduction in technology index from $25.33 \%$ during $2012-13$ to $40.75 \%$ during 2010-11 exhibited the feasibility of the demonstrated technology in this region. The similar observations were also obtained in blackgram crop by Bairwa et al., (2013) and also Hiremath and Nagaraju (2010).
During the study period, Human Resources Development Components i.e. farmers/farm women trainings, radio talks, field days, CD shows, popular articles, Kisan Melas, popular articles, crop production literatures and Kisan Sangosthi were also taken to increase the farmers understanding and skill about the recommended practice on black gram production.

The result of front line demonstration convincingly brought out that the yield of black gram could be increased more with the intervention on varietal replacement i.e. HYV PU-35, IPU 94-1 and T-9 in the Umaria district. To safeguard and sustain the pulse security in India, it is quite important to increase the productivity of black gram under limited resources, especially water. Favorable benefit cost ratio is self-explanatory of economic viability of the demonstration and convinced the farmers for adoption of improved production technology of black gram. The technology suitable for enhancing the productivity of black gram and calls for conduct of such demonstration under the transfer of technology programme by KVKs.

\section{References}

Bairwa, R.K., Verma, S.R., Chayal, K. and Meena, N.L. (2013). Popularization of Improved Black gram production technology through front line demonstration in humid southern plain of Rajasthan. Indian Journal of Extension Education and R.D. 21:97101

Choudhary, B.N.1999. Krishi Vigyan KendraA guide for KVK mangers. Publication, Division of Agricultural Extension, ICAR; 73-78.

Dubey S, Tripathi S, Singh P. and Sharma, R.K. (2010). Yield gap analysis of black gram production through front line 
demonstration. J. Prog. Agric. 1 (1): $42-$ 44.

Gurumukhi, D.R. and Mishra, Sumit, 2003. Sorghum front line demonstration-A Success story. Agril. Ext. Rev. 15(4): 22-23.

Hiremath, S.M. and Nagaraju, M.V. (2010). Evaluation of front line demonstrations on the yield of chilli. Karnataka $J$. Agric. Sci., 23 (2):341-342.

Sharma, O.P. (2003). Moth bean yield improvement through front line demonstration. Agril. Ext. Rev., 15 (5):11-13.

Tiwari, R.B., Singh, Vinay and Parihar, Puspa (2003). Role of front line demonstration in transfer of gram production technology. Maharastra J. Ext. Edu., 22(1): 19 .

Tomar, L.S., Sharma, P.B. and Joshi, K. (2003). Study on yield gap and adoption level of potato production technology in gird region. Maharastra J. Ext. Edu. 22(1): 15-18.

Yadav, D.B., Kamboj, B.K. and Garg, R.B. (2004). Increasing the productivity and profitability of sunflower through front line demonstrations in irrigated agroecosystem of eastern Haryana. $J$. Agron. 20:33-35.

\section{How to cite this article:}

Sahare, K.V., B.K. Tiwari, K.P. Tiwari, R.R. Singh, K.S. Baghel and Smita Singh. 2018. Performance of Frontline Demonstrations on Productivity and Profitability of Black Gram (Vigna mungo) Through Improved Technologies under Rainfed Conditions. Int.J.Curr.Microbiol.App.Sci. 7(10): 930-935. doi: https://doi.org/10.20546/ijcmas.2018.710.103 